\title{
GEORGE BERKELEY (1685-1753) (II)
}

\author{
MUNOA ROIZ JL ${ }^{1}$
}

Percibir un objeto, sus presuntas dimensiones, su imagen precisa o confusa nos sirve para orientar nuestras sensaciones, situándolas en un cierto orden, de forma que nosotros podamos «obrar», es decir, manipular, elegir, tener ciertas sensaciones en lugar de otras.

En cuanto al célebre problema propuesto por Molyneux, autor de «Dióptrica», y reconsiderado por Locke, acerca del ciego congénito, Berkeley afirma: "Las cualidades perceptuales de la visión y el tacto no son idénticas; para un ciego congénito que bruscamente recobrase la visión las percepciones visuales son algo totalmente nuevo para las cuales él no conoce los términos correctos, y su relación con la experiencia táctil previa. El espectáculo visual de los objetos es un código de signos cuya única relación con su referente son las palabras del lenguaje».

En el caso del ciego congénito que tratamos, la inversión mental de la imagen delineada en la retina (luz y color), se impone para poder relacionar la información visual con el tacto (resistencia y presión) y consecutivamente llegar a obtener una interpretación espacial del entorno coherente con los datos sensoriales. Se trata de concertar la información sensorial y consecutivamente, obtener la coordinación adecuada de los datos informativos, mediante la experiencia.

Quien nos «habla» en este lenguaje debe ser, naturalmente, un Ente Superior, que ha predispuesto y ordenado las cosas de este modo. La conclusión derivada de este criterio es que los objetos propios de la visión constituyen un lenguaje universal del AUTOR de la Naturaleza.

Este lenguaje tiene por objeto instruir al hombre para regular sus acciones, con el fin de obtener lo que es necesario para su vida y evitar lo que puede dañarla o perjudicarla.

Pero el planteamiento del tema del ciego congénito, pone en evidencia el caso descrito en el Evan- gelio de San Juan (cap. 9.), ya que en el relato evangélico la recuperación de la visión es inmediata, sin que se mencione perturbación alguna derivada de la interpretación de las imágenes, percibidas por vez primera por un adulto privado totalmente de experiencia visual previa. ¿Aportó el milagro el código de interpretación de las sensaciones visuales, de acuerdo con lo expuesto acerca de la función de percibir? ¿Percibió las imágenes invertidas? ¿Cómo interpretó de inmediato la visión cromática? ¿Los movimientos oculares alteraron la estabilidad del entorno? La respuesta de Jesús (cap. 9. ver. 41) es sumamente ambigua en relación con la visión y el pecado, lo que parece involucrar a la Divinidad en la función perceptiva pero limitándola a su fundamento sensorial y al valor del objetivo benéfico frente al precepto religioso.

Locke había aceptado la categoría de sustancia como depositaria de distintas cualidades o propiedades que realmente son percibidas por nuestros sentidos, pero Berkeley era más consecuente con su empirismo, y determinó que solo se pueden percibir cualidades, no sustancias.

Para Berkeley, el mundo físico solo existía desde el punto de vista de lo que es susceptible de ser percibido.

En referencia a cosas impensables, sin relación con la percepción, le resulta completamente ininteligible. Como ya hemos mencionado anteriormente, existir es ser percibido.

Así, la teoría de la visión de Berkeley, según la cual el ojo no ve la realidad, sino tan solo ciertos signos que generan nuestras sensaciones, prueba la existencia de un lenguaje visual que, como el lenguaje común, ha sido fijado por el arbitrio de una Providencia, prueba más poderosa que cualquier otra a favor de la existencia de Dios.

Berkeley se reiterará en estos argumentos en su obra de 1733 titulada La teoría de la visión, o la defensa del lenguaje visual (Theory of Vision, or Visual Language, Vindicated and Explained).

\footnotetext{
1 Doctor en Medicina. San Sebastián. España. E-mail:
} 
La posibilidad de que un objeto no sea percibido en un momento determinado por ente alguno llevaría a concluir que no existe, dado que existir equivale a ser percibido. Berkeley resuelve la situación declarando que los objetos mantienen su existencia porque son percibidos continuamente en la mente de Dios, ente perceptor permanente y global, y que ello es, a su vez, prueba determinante de la existencia de Dios.

Así, Berkeley admite que Dios conoce todo lo que es objeto de nuestras sensaciones, pero niega que en Dios este conocimiento sea una experiencia sensible semejante a la nuestra, porque tal experiencia es incompatible con la perfección divina.

Dios emplea las sensaciones como signos codificados para expresar y comunicar al espíritu humano, sus propias concepciones. Se trata de un código descifrado y adaptado al receptor.
Los fundamentos de esta doctrina de existir como ser percibido, permitieron a Ronald Knox (1888-1957) escribir su famoso poema crítico e irónico:

Hubo un joven que dijo, «A Dios deberá resultarle sumamente extraño si halla que este árbol sigue existiendo cuando no hay nadie en el patio.» Estimado Sr::

Me extraña su asombro: Estoy siempre en el patio. Por eso el árbol seguirá existiendo: es observado por su affmo. DIOS. 